\section{CADBO}

NEW YORK-Among the emerging class of carbohydrate engineering firms, Carbohydrates International AB (CH1, Arlov, Sweden) seemed most likely to succeed. Endowed with top researchers and key patents, the company (owned by AB Volvo, Gothenburg, Sweden) offered unique synthetic oligosaccharides to researchers, while developing carbohydrate-based products in clinical diagnostics and therapeutics. It had hoped to market the first of these-a test and treatment for urinary tract infection-by the end of this year. Yet now, only months after it was sold by Volvo to the small Swedish firm Medicarb (Stockholm), CHI has closed down.

"This came as a surprise," says Per O. Sundin, who headed the firm's Chicago office. When Volvo decided it no longer wanted to invest in carbohydrate research, it gave CHI permission to shop for a new owner. Company executives met with several large U.S. and Japanese pharmaceutical companies. But CHI's president, Torbjörn Moller, "wanted a Swedish financial and corporate base. And that was a problem, with 'poor' ven-
ENGINEERING FIRM DI ture capital in Sweden and marketing efforts concentrated in the U.S. market," according to Sundin.

At first, new owner Medicarb seemed a good choice. From its small factory in Bromma, the firm produces heparinization compounds and fine chemicals, and does some work with lectins. The sale was agreed upon quickly-over a single weekend, it is rumored, and without the consent of Medicarb's advisory board. Almost as quickly, CHI was in deep financial trouble.

"I think everybody panicked," says Sundin. With two of the strongest carbohydrate groups joined, expectations had been very high. But Medicarb's small staff had difficulty running CHI, which boasted a catalog of over 100 carbohydrate compounds. Within months of the February 1988 purchase, Medicarb's board and its financial backers withdrew their support, and CHI collapsed.

With the demise of $\mathrm{CHI}$, fewer companies will be able to take advantage of opportunities for using unique synthetic carbohydrate sequences. These sequences, often asso-

\section{DIGESTID}

ciated with proteins, are information carriers and play important roles in cell-cell recognition and binding. For example, many microorganisms infect their hosts only when they can bind to specific carbohydrate antigens on the host's cell membranes. Synthetic glycoproteins, or antibodies to glycoproteins, can be engineered to exploit this specificity-targeting drugs to specific body tissues or blocking a microorganism from binding to host membranes. Carbohydrates International was one of the few companies offering sale of "standard" and custom synthetic carbohydrate sequences, as well as licenses to specific carbohydrate production techniques.

Sundin has spoken with some venture capital firms about starting a new company to commercialize synthetic carbohydrates, and has found them alert to the potential of this technology. But, he says, "Restarting would require substantial funding, for relocating key researchers in Sweden to the U.S. and to provide the long-term financing needed for developing diagnostic products." -Pamela Knight

\title{
OSIID WATER PURIFICATION SYSTEMS
}

Systems and components for all water purification requirements.

\section{REVERSE OSMOSIS $\square$ ULTRAFILTRATION $\square$ MICROFILTRATION $\square$ DEIONIZATION \\ $\square$ standard pre-engineered systems \\ free water analysis service \\ $\square$ complete Authorized Distributor program \\ $\square$ experienced technical service and support}

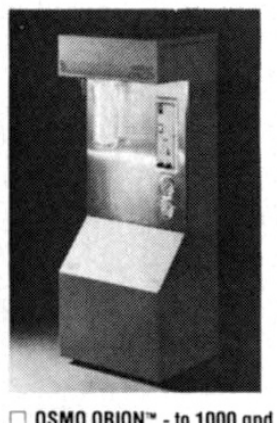

(158 Iph)

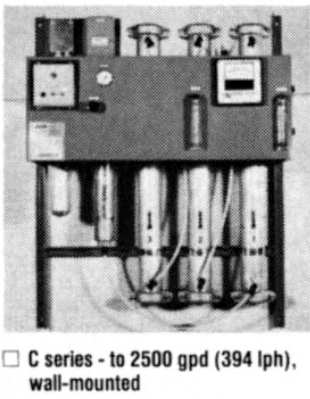

GUARANTEED: ALL OSMO equipment is guaranteed by a financially strong company that is committed to support you after the sale.

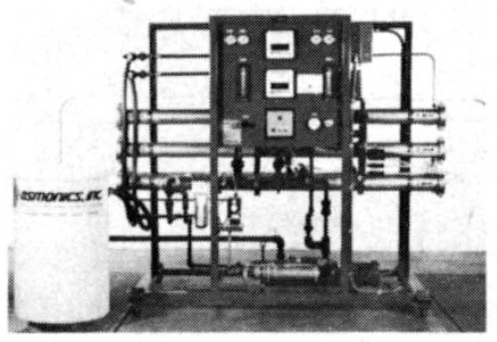

CHF Series - to 100,000 gpd $\left(379 \mathrm{~m}^{3} / \mathrm{d}\right)$

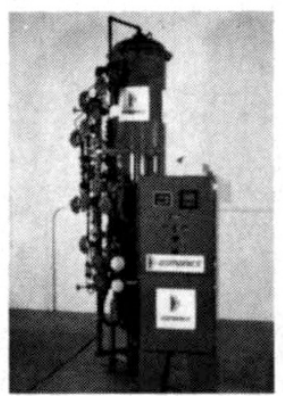

Mixed Bed and Twin Bed DI
SINGLE SOURCE RESPONSIBILITY: Whatever your water treatment requirements, come to the single source. OSMONICS is the only company that manufactures all major components of our systems, including membrane, membrane elements, pumps, prefilters, pleated filters, DI equipment, electrical controls and complete systems.

\section{Join Osmonics' world of high tech filtration.}

Call Toll Free: 1-800/351-9008, ext. 300 (In Minnesota: 612/933-2277) TELEX: 29-0847 OSMONICS MTKA

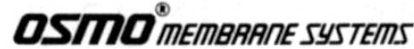

Division of Osmonics, Inc. 5951 Clearwater Drive

Minnetonka, MN 55343 USA

osmonics, וnc. 